\title{
ŠEIMOS, MOKYKLOS IR VALSTYBĖS BENDRADARBIAVIMAS UGDANT VAIKŲ SVEIKOS MITYBOS İPROČIUS
}

\author{
Julius Dovydaitis \\ Kauno kolegijos Medicinos fakultetas
}

Raktažodžiai: sveika gyvensena ir mityba, šeima, mokykla, valstybè.

\begin{abstract}
Santrauka
Vaikų sveika mityba tampa modernios visuomenès kultūriniu antropologiniu iššūkiu. Darbo tikslas - parengti vaikų sveikos gyvensenos (mitybos) ịpročių ugdymo ir atitinkamos sektorinès politikos įtvirtinimo darbinį-hipotetinị modelį. Straipsnyje, remiantis mokslinès literatūros, teisinių dokumentų analize, aptariamos vaikų sveikatos prastėjimo priežastys, nagrinėjama vaikų sveikatai palankios mitybos politika, programos, vaikų sveikatos stebėsenos priemonès. Vaiko teisių ir sveikatos apsaugos standartams kylant, vaikų sveikos mitybos tendencijos ir sveikatos būklè prastejja. Atskleidžiamos šio paradokso pagrindinès priežastys - maisto chemizacija, maisto energetinè struktūra (kaloringumas), vaikų hipodinamija, maisto rengimo ir saugojimo technologijų bei maitinimosi sociokultūrinių ritualų kaita. Hipotezès teisėmis pateikiamas darbinis modelis (1 lentelè), kuriame išgrynintos valstybès, mokyklos ir šeimos funkcijos, formuojant vaikų sveikos mitybos ịpročius bei ịtvirtinant atitinkamą sektorinę politiką.
\end{abstract}

\section{Ivadas}

Kai kurių pavojingų ligų paplitimo gyventojų populiacijoje statistiniai rodikliai nuolat prasteja, nors medicinos mokslo ir praktikos pažanga akivaizdi. Ši tendencija plinta moderniose gerovès valstybėse, kuriose į ligų prevenciją, sveikatos politiką, finansavimą, medicinos technologinị aprūpinimą žiūrima atsakingai. Tai nutukimas, širdies ir kraujagyslių ligos, II tipo diabetas, ortopedinès ligos, trumparegystè, nervų ir psichinès ligos, ịvairių alergijų epidemija ir kt. [1,10,12,18,32].

Autorius, analizuodamas vaikų ir studentų sveiką mitybą kaip sektorinių politikų koordinuojamą objektą [35], pabrèžia, kad šiandien susiduriame su gyvenimo būdo ir civilizacijos ligomis. Šios ligos, kaip ir visos kitos, turi savo kilmès biologinius ir fiziologinius mechanizmus, raidos ir progresavimo désningumus. Nekelia abejonių tai, kad viena iš svarbiausių minètų ligų kilmès, masinio paplitimo ir progresavimo priežasčių yra šiuolaikinio žmogaus gyvenimo būdas $[5,7]$. Aukštas mechanizacijos ir technologijų lygis eliminavo būtinybę žmogui kasdien, nuolatos, sunkiai fiziškai dirbti. Juk evoliucija sukūrè žmogų, kaip fiziškai labai aktyvų organizmą. Fizinis aktyvumas nustojo būti ekonomine egzistencine būtinybe ir virto laisvo pasirinkimo ir laisvalaikio dalyku. Vienas iš labiausiai šiuolaikinèse medijose paplitusių naratyvų yra visuotinis raginimas būti fiziškai aktyviam, sportuoti [16], tačiau realybė yra tokia, kad didžioji dalis įvairaus socialinio sluoksnio ir amžiaus žmonių, įskaitant vaikus, fizinio aktyvumo požiūriu išlieka labai pasyvi.

Darbo tikslas - parengti vaikų sveikos gyvensenos (mitybos) ịpročių ugdymo ir atitinkamos sektorinès politikos įtvirtinimo darbinį-hipotetinị modelị.

\section{Tyrimo medžiaga ir metodai}

Tyrimo medžiagą (empirinę bazę) sudaro: 1) žmogaus (ypač vaikų ir jaunimo) sveikatos statistikos tendencijos; 2) maisto gaminimo, saugojimo ir vartojimo technologinès ir sociokultūrinès tendencijos; 3) sveikos mitybos politikos raiškos ir ịtvirtinimo tendencijos modernioje visuomeneje.

Naudojant mokslinès literatūros šaltinių, teisès aktų, strateginių dokumentų ir žinybinès statistikos analizės metodus, hipotezès teisėmis yra sukurtas vaikų sveikos gyvensenos (mitybos) ịpročių ugdymo ir atitinkamos sektorinès politikos itvirtinimo darbinis modelis.

\section{Tyrimo rezultatai}

Sveika vaikų mityba - kultūrinis antropologinis modernios visuomenès iššūkis. Šiuolaikinio žmogaus mityba yra savarankiškas vadinamujjų civilizacijos ir gyvenimo būdo ligų šaltinis. Visų pirma, tenka kalbėti apie sunaudojamų kalorijų kiekị ir maisto energetinę-cheminę struktūrą. Kitas svarbus dèmuo - fizinis aktyvumas, kadangi subalansuotos ir sveikos mitybos, kuri būtų atsieta nuo individo fizinio 
aktyvumo, tiesiog nèra. Ne vien kalorijos ir jų perteklius šiandien pagrindinė problema. Reikšmingas rizikos veiksnys yra maisto chemizacija. Išsivysčiusiose šalyse - JAV, ypač ES, keliami labai aukšti ir griežti maisto saugos reikalavimai. Tiktai ar šiandien galètume teigti, kad tikrai valgome gerokai sveikesnị maistą, nei tas, kuris buvo valgomas prieš 40 ar 70 metu??

Maisto chemizaciją skatina ir vis didejjanti gamtinès aplinkos tarša. Netgi vandenyno žuvis šiandien yra užteršta (pvz., kad ir sunkiaisiais metalais), todèl šiuo atveju kalbèti apie sveiką mitybą darosi problemiška ${ }^{1}$. Aplinka užsiteršia ir dèl intensyvaus chemizuoto žemès ūkio, kuris gamina pagrindinius maisto išteklius žmogui ir pašarus galvijams.

Visos planetos mastu didejjanti gyvūninès kilmès maisto paklausa verčia intensyvinti mèsos gamybą ir nuolat didinti mèsininkystès ekonominị našumą. Mèsai auginti vis plačiau naudojami augimą skatinantys hormoniniai preparatai ${ }^{2}$. Egzistuoja teorija, jog vis ankstejjanti mergaičių menarchẻ ir akceleracija yra nenatūraliai išprovokuota hormoninių preparatų, kurie ị vaiko organizmą patenka kartu su mésos produktais. Didžiulè galvijų sankaupa modernioje ir našioje fermoje sukelia galvijų ligas, kurios gydomos ir preventuojamos antibiotikais ${ }^{3}$. Mikrobiologai ir medikai įspeja, kad grèsmingai didèja bakterijų štamų atsparumas antibiotikams ir jau šiandien tai tampa grèsmingu iššūkiu šiuolaikinei medicinai. Nekelia abejonių, kad šito priežastis yra net tik gyventojų (galbūt ir kai kurių medikų) piktnaudžiavimas antibiotikais ir savigyda, bet ir masinis antibiotikų naudojimas mèsininkysteje.

Maisto žaliava šiandien yra smarkiai chemizuota. Maža to, antroji (ir galbūt sveikatai dar pavojingesnè) chemizacijos banga kyla dèl maisto perdirbimo pramoneje naudojamų technologijų. Žinoma, sveikas maistas ir sveika mityba šiandien yra nekvestionuojama vertybè, kurios nei gamyba, nei prekyba ignoruoti negali. Deja, sveiko maisto idealas šiandien labiau įtvirtintas tik rinkodaroje ir reklamoje, vaizdžiai tariant „pažaduose ir deklaracijose“, bet ne faktiniuose maisto produktu gamybos ir sandèliavimo procesuose. Neoliberalistiné pasaulèžiūra, totaliai ịsitvirtinusi šiuolaikiniame gamybos būde, aukščiau visko iškelia naudos, našumo ir ekonominio racionalumo reikalavimus. Būtent iš

${ }^{1}$ Fuhrman J. Fish: Pollution Risks. 2006 [žiūrèta 2016m. kovo 25d.]. Prieiga per internetą: http://www.diseaseproof.com/archives/toxins-fishpollution-risks.html

${ }^{2}$ Storrs C. Hormones in food: Should You Worry. 2011 [žiūrèta 2016m. sausio 15d.]. Prieiga per internetą: http://www.huffingtonpost. com/2011/01/31/hormones-in-food-should-y_n_815385.html

${ }^{3}$ Organic Milk Vs. Regular Milk: Why I'm Ditching Organic. [žiūrèta 2016m. kovo 10d..]. Prieiga per internetą: http:/fitnessreloaded.com/ organic-milk-vs-regular-milk/ čia išplaukia keli esminiai šiuolaikinès maisto pramonès ir prekybos postulatai. Antai, maisto savikaina turi būti kuo mažesnè, skonio ir kvapo savybės akivaizdžios, labai patraukli produkto išorè, o produktas lengvai transportuojamas, ilgai sandèliuojamas, ilgai negendantis. Visų šių reikalavimų išpildymas neišvengiamai susijęs su dar didesne chemizacija ir produkto maistinès kokybès suprastejimu. Technologiniuose procesuose gamybininkai priversti masiškai diegti tokius triukus, kaip: 1) kuo pigesnès maistinès žaliavos naudojimas (pigių transriebalų, pieno miltelių, ịvairių koncentratų, sojos priedų, pigių GMO produktų ir pan.); 2) platus skonio ir kvapo stipriklių naudojimas; 3 ) gausus maistiniu dažų, emulgatorių, stabilizatorių naudojimas, užtikrinantis patrauklią išorinę produkto išvaizdą; 4) gausus konservantų ir antioksidantų naudojimas, gerokai atitolinantis produkto gedimą, pratęsiantis produkto transportavimo, sandèliavimo ir galiojimo laiką.

Nereiktų klaidingai galvoti, kad visa tai yra kažkur toli, tik ne Lietuvoje, ne Europos Sajungoje. 2010-2012 m. LR Seime ${ }^{4}$ buvo parengtas vaikų sveikos mitybos politikos požiūriu tikrai vertas dèmesio įstatymo projektas. İstatymu buvo ketinama ịpareigoti gamintojus ir prekybininkus pakuotèse, kai reikia, naudoti užrašą „,Šis produktas gali būti kenksmingas Jūsų vaiko sveikatai“". Šiuo teisès aktu buvo siekiama stabdyti bent jau kūdikių ir vaikų maisto nežabotos chemizacijos tendenciją, preventuoti tokị reiškinį, kaip masinis vaikų sirgimas alerginėmis ligomis. Deja, maisto pramonès lobistai įtikino ịstatymo leidejjus, kad ịstatymas nerealus, žalingas, pakenks vietos verslui, nes, pasak ekspertų, net iki 60-70 proc. Lietuvos (!) gamintojų produkcijos turètų būti paženklinta tokiu užrašu.

Lietuvoje 2016 metais buvo sugriežtintas vaikų maitinimo mokykloje teisinis reglamentavimas, kas iš tiesų yra visapusiškai sveikintina ${ }^{5}$. Paaiškejjo, kad dabar mokyklų valgykloms dèl sugriežtintų reikalavimų tiesiog nebetinka kai kurie įprastiniai produktai ir maistinès žaliavos, kurias gyventojai perka prekybos centruose ar urmo sandèliuose... Šis pavyzdys parodo, kaip toli nuejo maisto chemizacija, piktnaudžiavimas visokiais abejotinais priedais ir pan.

Dar vienas maisto produktų chemizacijos didinimo ir

${ }^{4}$ Seimo narès A.Zuokienės parengtas PASIŪLYMAS Dèl LR maisto istatymo 2 straipsnio papildymo ir papildymo 61 straipsnių ịstatymo projekto Nr.XIP-1733 [žiūrèta 2016m. kovo 10d.]. Prieiga per internetą: http:// www3.lrs.lt/pls/inter3/dokpaieska.showdoc_1?p_id=382353; Seimo Darbo partijos frakcijos narès, Sveikatos reikalų komiteto narès Dangutès Mikutienès pranešimas: „Pašvinkusi sveikatos politika - skanaus!“ (2012). [žiūrèta 2016m. kovo 10d.]. Prieiga per internetą: http://www.lrs.lt/sip/ portal.show?p_r=15371\&p_k=1\&p_t $=119643$

${ }^{5}$ Seime diskutuota apie mokinių maitinimo problemas. [žiūrèta 2016 $\mathrm{m}$. kovo 10d.]. Prieiga per internetą: http://lsveikata.lt/aktualijos/seimediskutuota-apie-mokiniu-maitinimo-problemas-4082 
kokybės suprastejjimo šaltinis yra pakuotès, tiksliau - pakuočių cheminè sudètis. Pramonejje ir prekyboje taip populiarus plastikas ir jo atmainos yra labai problemiška pakuotė dèl itin nuodingos medžiagos ir kancerogeno - bisfenolio [9]. Tyrimai rodo, kad vos 1-2 metų vaikų organizme jau randama bisfenolio pèdsakų [11]. Kadaise stikliniai kūdikių maitinimo buteliukai, mediniai, medžiaginiai žaislai šiandien yra visuotinai keičiami plastiku. Plastikas plačiai naudojamas vaikų mėgstamo maisto pakuotems ir pan. [3]. Medijose vis nuvilnija skandalingi pranešimai apie masinị vaikiškų plastikinių žaislų išèmimą iš prekybos dẻl nustatyto žaislų nuodingumo. Didžiule problema yra tai, kad netgi ES - valstybių susivienijime, kur maisto saugos ir vartotojų teisių standartai kraštutinai aukšti, iki šiol nèra griežčiau reglamentuojama, kontroliuojama pakuočių kokybè vartotojų sveikatos požiūriu'.

Esminè vaikų sveikos gyvensenos ir sveikos mitybos įtvirtinimo priemonè galètų būti maitinimo organizavimas mokyklose. Pagal šalies ịstatymus, ši funkcija patikèta vietos savivaldybių administracijoms, kurios yra ikimokyklinių ir bendrojo ugdymo ịstaigų steigejos. Pastaraisiais metais Lietuvoje buvo priimti teisès aktai, kuriais siekta kardinaliai tobulinti vaikų valgiaraščius ugdymo įstaigose pagal paskutinį sveikatos mokslų žodị. Deja, tai sukèlè dalies vaikų ir jų tèvų neigiamą reakciją, esą, maistas neskanus ir vaikai jo atsisako. Viena iš galimų priežasčiu yra tai, kad bent dalies šeimų mitybos ịpročiai smarkiai skiriasi nuo mokslu paremtos sveikos mitybos sampratos. Jei vaikas ịpratęs prie riebaus, saldaus arba sūraus maisto, jo subjektyvus nepasitenkinimas moderniu sveiku valgiaraščiu yra suprantamas, bet vargu ar pateisinamas. Paminètinas dar vienas probleminis vaiku maitinimo ugdymo įstaigose aspektas. Remiantis masto ekonomika ir taupant lèšas, vaikų maitinimo paslauga centralizuojama. Naikinamos stacionarios valgyklos, kurios buvo įrengtos projektuojant pastatus, o paslauga viešųų pirkimų būdu deleguojama privačiam teikejjui, kuris induose išvežioja maistą i vietas. Minètų paslaugų sektoriuje aptikta nemažai piktnaudžiavimo, be to, atitinkamos vaikų maitinimo organizavimo praktikos trūkumus smarkiai kritikuoja Lietuvos tėvų organizacijos, mokytojai.

Aptartos aplinkybės ir tendencijos rodo, kad sékmingas vaikų sveiko ir kokybiško maitinimo klausimo sprendimas vargiai įmanomas, jei apsiribojama vien organizacijos (mokyklos) ar savivaldybès administracijos lygmeniu. Čia

${ }^{6}$ Iš ko valgo ir geria mūsų vaikai. Mamos žurnalas.[žiūrèta 2016 m. kovo 30d.]. Prieiga per internetą: http://mamoszurnalas.lt/ko-valgo-ir-geria-musu-vaikai/

${ }^{7}$ „Socdemių akademija“. Kokị kelią renkasi Lietuvos mokyklos?“ [žiūrèta $2016 \mathrm{~m}$. sausio 15d.]. Prieiga per internetą: http://1sdms.lt/index.php/2renginiai/177-socdemi-akademija-koki-kelia-renkasi-lietuvos-mokyklos reikalingas valstybinis požiūris, valstybinè sveiko vaikų maitinimo politika, specialios programos, atitinkamas teisinis reguliavimas ir politikos igyvendinimo stebèsena bei kontrolè. Reikia ir socialiai jautraus, netgi subtilaus požiūrio. Lietuvoje bendrojo lavinimo mokyklos moksleiviai iš ekonomiškai silpnesnių šeimų gauna nemokamą maitinimą. Vis dèlto paaiškėjo, kad kai kurie mokiniai gèdijasi nemokamo maitinimo paslaugos ${ }^{7}$, kadangi netiesiogiai paviešinama šeimos ekonominè padètis. Pasirodo, nepilnamečiai yra tokiam dalykui jautrūs, tai, matyt, traumuoja jų savimonę ir savivertę, vaikai bijosi tapti bendraamžių patyčių objektu. Pasiryžę geriau mokykloje būti nevalgę, negu paviešinti savo šeimos statusą. Yra mokyklų, kur gera pusė vaikų gauna nemokamą maitinimą. Atsižvelgiant ị tai, LR Seime buvo teikta įstatymo pataisa ${ }^{8}$, kad nemokamą maitinimą gautų visi pradinių klasių moksleiviai, nepriklausomai nuo jų tėvų socioekonominio statuso. Pataisa LR Seime ekonomijos sumetimais buvo atmesta.

Moderni vartotojiška visuomene keičia individo ir šeimos maitinimosi ịpročius. Čia turima galvoje ne tik produktų biocheminis turinys, kokybė, bet ir namų ūkyje taikomos maisto paruošimo buitinès technologijos, maisto vartojimo namų ūkyje paprotiniai ir kultūriniai ritualai. Dar prieš gerus 50-80 metų netgi ir miestiečio šeima paprastai visą maistą ruošdavo pati, dominuodavo natūralūs produktai, ịvairių pusgaminių, konservuotų ir chemizuotų, labai išgrynintų, padidinto kaloringumo nesveikų produktų beveik nebuvo. Valstietiškas kaimas iš esmès tebegyveno pagal natūrinio ūkio dėsnius ir bemaž viską užsiaugindavo, pasigamindavo pats. Kuo toliau, tuo labiau suvokiama etninio kulinarinio paveldo išskirtinè vertè. Galima daryti prielaidą, kad savitoje gamtinejje klimatinejje aplinkoje gyvenanti žmonių populiacija natūraliai (evoliuciškai ir kultūriškai) yra pripratusi būtent prie tam tikrų maisto produktų ir visa tai, tikètina, pozityviai susiję su sveikatingumu. Žinoma, hipodinamijos link judantis šiuolaikinio žmogaus gyvenimo būdas, globalizacijos lemtas žmonių geografinis mobilumas, kultūrų, tradicijų ir papročių maišymasis šią tendenciją gerokai susilpnino.

Su didžiule nostalgija šiandien suvokiame, kad maisto pasigaminimo ir valgymo šeimos rate kultūrinis dvasinis ritualas modernybès sąlygomis vis labiau nyksta. Tai ne vien fiziologinis aukštesniųjų žinduolių - homo sapiens - maisto prièmimo aktas, tegul ir gyvybiškai labai svarbus. Ne mažiau

${ }^{8}$ Dudènas A. Nemokamas maitinimas visiems mažiesiems užkirs kelią patyčioms. [žiūrèta 2016 m. kovo30 d.]. Prieiga per internetą: http://www. delfi.lt/news/ringas/politics/a-dudenas-nemokamas-maitinimas-visiems-maziesiems-uzkirs-kelia-patycioms.d $\mathrm{id}=68654810$; Seimas svarstys pataisas dèl nemokamo maitinimo pradinukams ir priešmokyklinukams (projektas Nr. XIIP-2995). (2015). [žiūrèta 2016m. kovo 30 d.]. Prieiga per internetą: http:/www3.1rs.1t/pls/inter/w5_show?p_r=4445\&p_d=158597\&p_k=1 
svarbus yra dvasinis ir kultūrinis šios procedūros turinys. Maisto vartojimas evoliuciškai susijęs su individo ar jų grupès saugumo, tikrumo ir ramybės jausmu. Galbūt kova už maistą, nuolatinès pastangos jo gauti susijusios su fizinių ir dvasinių jègų mobilizacija, įtampa. Kad ir kaip būtų, pati valgymo procedūra labiau susijusi su ramybe, relaksacija ir tam tikru dvasingumu, socialumu. Evoliucijos požiūriu natūralu, jog smegenų centrai, atsakantys už ramybès ir sotumo pojūtí, neatsitiktinai smegenų žievèje pozicionuojasi greta.

$\check{C}$ ia galima prisiminti kultūrinius elgesio ritualus, ateinančius iš žmogaus istorinių civilizacijų. Pavyzdžiui, buvo tikima, jog nudobtas žvèris turi dvasią, buvo dèkojama dievams už padovanotą grobị, atsiprašoma nudobto žvėries sielos, iš grobio liekanų (dantų) gaminami amuletai, išdirbamas kailis... Žemdirbiškose kultūrose pagrindinių augalinių kultūrų, kurios sudare mitybos pagrindą, sèja, derliaus nuemimas paprastai ịgauna mistinị turinị ir tiesiogiai siejasi su tautos, genties tikejjimu, dvasiniais religiniais ritualais. Tuos dalykus detaliai atskleide kultūros antropologai, 19-20 a. masiškai lankę ir tyrinėję primityvias tauteles kolonijose.

Visai nebūtina mintinio eksperimento būdu nusikelti i mūsų civilizacijos ištakas. Natūriniame žemdirbio ūkyje funkcionuojanti šeima paprastai turèdavo galimybę kasdien kelis kartus sukviesti visus šeimos narius prie bendro stalo. Prie pietų stalo neretai kartu susėsdavo mažiausiai trys tos šeimos generacijos - seneliai, tèvai, vaikai, vaikaičiai... Iš etnografinių tyrimų žinomi kultūriniai šios procedūros ritualai. Vyriausias šeimos narys persižegnojimu ir trumpa malda paskelbia pietų pradžią, raiko duoną ir pan. Netyčia nukritęs duonos gabalëlis pabučiuojamas... [8]. Akivaizdu, kad šeimos pobūvis prie kasdienio ar juolab šventinio stalo kartu buvo ir subtilaus dvasinio bendravimo forma. Po pietų būdavo poilsis. Šiltuose kraštuose jis trukdavo geras 4 valandas, kuomet nepakeliamam karščiui nuslopus, žmonès vẻl galèjo būti fiziškai aktyvūs. Darbuose prapuolusiame Lietuvos kaime taip pat buvo praktikuojamas vadinamasis pokaitis.

Šiuolaikinè modernizacija sugriauna ir tam tikrą maisto gaminimosi bei maitinimosi dienotvarkę, kultūrinị ritualą, galiausiai pakeičia ir artimų žmonių dvasinio bendravimo formą. Visus tuos ritualus išardè fabrikinè-konvejerinè gamyba, kuomet vadinamajai pietų pertraukai buvo skiriama ne daugiau kaip 1 val. laiko, o tas laikas praleidžiamas asketiškoje „kantinoje“ - kareivinių ar kalëjimo tipo valgykloje. Moderni postindustrinès visuomenès šeima patiria gilumines transformacijas. Dažniausiai tai nebėra trijų generacijų šeima, tai nebūtinai pilna šeima ar šeima su 2-3 vaikais. It buiț ir maitinimąsi ịsiveržè chemizuoti ir konservuoti produktai, pusfabrikačiai, greitas maistas, mikrobangu krosnelè ir t.t. Šeimos nariai ị savo darbus ir mokyklas išeina skirtingu laiku ir ị namus grịžta skirtingu laiku. Vieni maitinasi kavinejje prie darbovietės, kiti mokykloje. Net ir tuo atveju, jei pajamos leistų kasdien pasimėgauti gero restorano, kuris niekada nenaudoja pusfabrikačių, paslaugomis, šiuo malonumu dažniausiai neįmanoma pasinaudoti dèl laiko stokos, dèl įtempto darbo dienos ritmo ir tempo šiuolaikineje stresuojančioje ir konkuruojančioje organizacijoje. Šiuolaikinès šeimos dienotvarkejje tiesiog nebelieka laiko išteklių visam natūralaus maisto gamybos ir vartojimo ciklui. Geriausiu atveju tai yra savaitgalio ar švenčių dienos prerogatyva, laisvalaikis ir hobis. Galiausiai tas laisvalaikis neretai pasireiškia bulvių traškučių ar saldumynų valgymu prie televizoriaus...

Nagrinėjant suaugusiujų ir vaikų sveikos mitybos klausimą, pastaruoju metu vis dažniau tenka susidurti su paradoksalia, tačiau vis stiprejjančia ir iš dalies rizikinga tendencija. Tai ịvairių dietų, įskaitant radikalų veganizmą, žaliavalgystę, svorio sureguliavimo dietas ir pan. fetišizavimas. Kaip ir kiekviena medicininè terapine priemonè, dieta turi būti taikoma profesionaliai. Dieta gali ir padeti, ir pakenkti. Populiariojoje sveikatingumo literatūroje, žiniasklaidoje gausiai propaguojamos ịvairios radikalios, moksliškai ne iki galo patikrintos dietos. Atitinkamos medijų žinutès autoriai ir leidejjai beatodairiškai visiems, nepriklausomai nuo amžiaus, sveikatos būklès ,garantuoja“" visišką pagijimą nuo sunkiausių, nepagydomų ligų, tobulą sveikatą, grožị, lieknumą... Tarp merginų plinta sveikatai žalingas lieknejjimas, kuris dažnai baigiasi pavojinga liga - anoreksija. Tarp vaikinu plinta susigundymas tapti raumenų kalnu ,per 1 ménesị“. Nesaikingai, nesubalansuotai pradedama naudoti ịvairius mitybos papildus sportininkams, netgi klastingus vaistus, kaip antai, anaboliniai steroidai ir pan. Medijų vaidmuo propaguojant sveiką gyvenseną ir mitybą yra kontraversiškas, nes medijose aptiksime ir pažangių, naudingų žinučių, ir žmogaus bei vaiko sveikatai pavojingos dezinformacijos.

Vertas dèmesio toks fenomenas, kada vaikai auga šeimose, kur tèvai yra fanatiškai persisėmę kokios nors radikalios dietos idejja ir natūraliai primeta atitinkamą gyvenimo bei maitinimosi būdą savo vaikams. Tokie tèvai neretai reiškia pretenzijas, kartais pagrịstas, o kartais ir ne, dèl valgiaraščio parinkimo ir maitinimo mokykloje [17]. Jei kalbama apie vaikystę ir radikalias dietas, tai neapibrěžtumas ir rizika čia labai dideli. Trūksta kol kas tuo klausimu patikimų longitudinių mokslinių studijų. Atitinkamos maitinimosi mados masiškai išplito istoriškai neseniai, todẻl dar ir reprezentatyvių studijų nėra apie tai, kaip funkcionuoja žmonių, kurių vaikystė ir ontogenezė vyko radikalių dietų sąlygomis, organizmas. Kaip, lyginant su analogiška mišria gyventojų populiacija, atrodo tokių radikalių dietininkų sveikata ar viso gyvenimo sveikatos istorija - paauglysteje ir jaunysteje, jauno suaugusiojo amžiuje, brandos laikotarpiu, senatveje? Vienareikšmiškų ir patikimų atsakymų ị tokị klausimą nei 
tarptautinis, nei Lietuvos mokslas šiandien dar neturi. Fiziologinès hipotezès teisėmis galima išsakyti kai kuriuos samprotavimus. Naujagimis, kol pasiekia pilnametystę ir fiziologinę brandą, daugybę kartų padidina savo kūno masę, formuojasi individo kaulų, raumenų ir smegenų struktūros. Radikalios dietos, iš kurių struktūros visiškai eliminuojama mėsa, žuvis, pieno produktai, sveikos vaikų mitybos požiūriu kelia daug klausimų. Didelès abejonès dèl tokių dietų rizikos intensyviai augančiam organizmui neišsklaidytos.

Visiškai akivaizdu, jog sunkoka kalbèti apie sveiką mitybą atsietai nuo suaugusiojo, taip pat ir vaiko, fizinio aktyvumo [26]. Esant skirtingam fizinio aktyvumo režimui, vienas ir tas pats meniu gali būti apibūdintas kaip sveikas arba nesveikas. Šiuolaikinis gyvenimo būdas, mechanizacija, urbanizacija, kompiuterizacija sukūrè tokią vaikų ir paauglių socializacijos aplinką, kurioje drastiškai sumažèjo vietos judesiui ir fiziniam aktyvumui. Pridèkime prie to dar ir maisto chemizaciją. Visa tai masiškai sukèlè tokias sunkias pasekmes, kaip vaikų nutukimas ir diabetas, stuburo ir laikysenos ligos, regejjimo sutrikimai, alergijos ir kitas [29].

Akivaizdu, kad susiduriame su paradoksu: modernioje vakarietiškoje visuomenèje, kaip niekada iki šiol, aukšti vaikų teisių ir vaikų sveikatos apsaugos standartai, tačiau vaikų mityba ir gyvenimo būdas sveikatos požiūriu ko gero yra prastesnis, nei jų bendraamžių prieš 50 ar 70 metų.

Vaikų sveikos mitybos politika ir stebėsena. Vaikų sveikos gyvensenos kontroversiškumo supratimas modernybės sąlygomis paskatino valdžios, visuomenès ir mokslo domejjimąsi šia sudetinga problema. Nuo 2003 metų ES vykdoma paauglių sveikos gyvensenos ir mitybos Europos šalyse stebėsena (HELENA ${ }^{9}$ ). Šios stebėsenos metu 10 Europos valstybių miestų vertinami paauglių mitybos ir fizinio aktyvumo ịpročiai, mitybos būklè, atskleidžiamos žinios ir požiūris ị mitybą, fizini aktyvumą, maisto pasirinkimą, analizuojami regioniniai, kultūriniai, socialiniai, genetiniai ir lyčių skirtumai (panašumai), siekiama plèsti sveiko maisto gamintojo skaičiu bei nustatyti rinkodaros strategijas vartotojams, kad būtų pagerinta paauglių mityba $[13,25,27]$.

2006-2012 metais vykdytas tyrimas „Mitybos problemų atpažinimas ir prevencija bei gyvenimo būdo sukeltas poveikis sveikatai vaikysteje ir kūdikysteje" (IDEFICS ${ }^{10}$ ). Tai Europos studija ${ }^{11}$, tirianti 2-10 metų vaikų mitybą, socialinius ir gyvenimo būdo veiksnius. Tyrimas orientuotas i

\footnotetext{
${ }^{9}$ Plačiau apie ši projektą žr. internetinę prieigą: Healthy Lifestyle in Europe by Nutrition in Adolescence. Projektas. Prieiga per internetą: http:// www.helenastudy.com/

${ }^{10}$ Plačiau apie šį projektą žr.internetinę prieigą: http://www.ideficsstudy.eu/Idefics/

${ }^{11}$ Plačiau apie šio projekto mokslinius radinius žr. internetinę prieigą: http://www.ideficsstudy.eu/Idefics/webcontent?cmd=innerDoc\&path=37 $89 \&$ start $=$ true
}

veiksnius, kurie turi įtakos antsvoriui ir susijusioms ligoms; siekiama sukurti naują ir inovatyvų vaikų požiūrị ị sveikesnę mitybą ir fizinį aktyvumą bei mokyti tèvus ir vaikus, didinti informuotumą dèl antsvorio ir nutukimo vaikystėje visoje Europoje, atsižvelgiama, kaip ir HELENA projekte, ị regioninius, kultūrinius, socialinius, biologinius ir lyčių specifinius skirtumus, formuojamos gairès mokslininkams ir politikams, siekiant veiksmingos ir efektyvios antsvorio rizikos prevencijos vaikysteje [6].

Panašios studijos atliekamos apie maisto pasirinkimą, mitybos ịpročius, gyvenimo būdo veiksnius paauglysteje, tėvų įtaką vaikų antsvoriui ir jų laisvalaikio praleidimo formas, socialinius veiksnius, tèvų šeimos vaidmenị ir vaikų gyvenimo būdą, šeimos gyvenimo būdą ir vaikų nutukimą, vaikų mitybos ịpročius ir užimtumą pertraukų metu mokykloje $[16,22,31,33]$. Lietuvoje mokslininkai atlieka tyrimus apie mokykloje vaikams tiekiamus patiekalus, moksleivių mitybos režimą, fizinio aktyvumo ir mitybos ryši su akademiniais pasiekimais bei elgesiu, ikimokyklinio amžiaus vaikų mitybą ir sveiką gyvenseną, mokytojų žinių apie sveikatą ir sveiką gyvenseną reikšmę mokinių sveikos gyvensenos ugdymui, pristatomi Lietuvos vaikų augimo stebėsenos rezultatai ir pokyčiai 2008-2013 metais, dalyvaujant tarptautiniame PSO Europos vaikų nutukimo stebėsenos iniciatyvos projekte (COSI), pirmokų mitybos ịpročiai $[4,14,15,23,30,34]$.

Taikomos tarpdisciplininès intervencinès programos, kuriomis siekiama tèvams suteikti praktinių, teorinių žinių apie sveiką mitybą ir nutukimą ikimokykliniame amžiuje $[2,21]$. Lietuvoje domimasi vaikų mitybos gerinimo programų veiksmingumu, kurių analizė parodè, kad programos atspindi ịvairius multidisciplininius aspektus, kurie apima mitybą, fizinį aktyvumą, antropometrinius ir KMI rodiklius, psichosocialinius veiksnius, vaikų žinias, elgseną [19,24]. Paminetini tarptautiniai ir nacionaliniai strateginiai dokumentai, teisés aktai, reglamentuojantys vaikų sveiką mitybą, tokie kaip Europos Komisijos Baltoji knyga dèl Europos strategijos su mityba, antsvoriu ir nutukimu susijusioms sveikatos problemoms spręsti ${ }^{12}$; Europos Bendrijų Komisija. Baltoji knyga. Kartu sveikatos labui, 2008-2013 m. ES strateginis požiūris ${ }^{13}$; Europos kovos su nutukimu chartija ${ }^{14}$; Žalioji

${ }^{12}$ Europos Komisijos Baltoji knyga dèl Europos strategijos su mityba, antsvoriu ir nutukimu susijusioms sveikatos problemoms spręsti - KOM(2007)279, Briuselis. [žiūrèta 2016 m. kovo 28 d.]. Prieiga per internetą: http://ec.europa.eu/health/archive/ $\mathrm{ph}$ _determinants/life_style/nutrition/documents/nutrition_wp_lt.pdf

${ }^{13}$ Europos Bendrijų Komisija. Baltoji knyga. Kartu sveikatos labui, 2008-2013 m. ES strateginis požiūris. Briuselis, 2007-10-23 KOM (2007) 630 galutinis. [žiūrèta $2016 \mathrm{~m}$. kovo 28 d.]. Prieiga per internetą: http://ec.europa.eu/health/ph_overview/Documents/strategy_wp_lt.pdf

${ }^{14}$ Europos Bendrijų Komisija. Baltoji knyga. Kartu sveikatos labui, 2008-2013 m. ES strateginis požiūris. Briuselis, 2007-10-23 KOM (2007) 630 galutinis. [žiūrèta 2016 m. kovo 28d.]. Prieiga per internetą: http://ec.europa.eu/health/ph_overview/Documents/strategy_wp_lt.pdf 
1 lentelė. Holistinis vaikų sveikos mitybos ịpročių ugdymo darbinis-hipotetinis modelis Šaltinis: parengtas autoriaus, remiantis mokslinès literatūros analize

\begin{tabular}{|c|c|}
\hline \begin{tabular}{|l} 
SOCIALINIAI \\
LYGMENYS
\end{tabular} & Socializuojančios ir edukacinès funkcijos \\
\hline \multirow[b]{2}{*}{$\begin{array}{l}\text { MAKRO } \\
\text { LYGMUO }\end{array}$} & Valstybinio lygmens funkcijos \\
\hline &  \\
\hline \multirow[b]{2}{*}{$\begin{array}{l}\text { MEZO } \\
\text { LYGMUO }\end{array}$} & Mokyklos funkcijos \\
\hline & $\begin{array}{l}\text { - Mokyklinių dalykų turinio (pvz., biologijos, kūno kultūros, technologijų, chemijos, } \\
\text { istorijos, socialinès geografijos etc.) išnaudojimas, tarpdalykinių didaktinių ryšių } \\
\text { užtikrinimas, formuojant holistinę mokinių sveikos mitybos sampratą } \\
\text { - Mitybos perversijų (radikalios dietos, papildai, dopingas, badavimas, anoreksija } \\
\text { ir kt.) prevencija } \\
\text { - Valgyklos ir maitinimosi kultūros puoselèjimas mokykloje, sveiko valgiaraščio ir } \\
\text { higienos puoselėjimas mokykloje, apsinuodijimų ir susirgimų prevencija } \\
\text { - Vaikų elgesio pertraukų metu stebėsena } \\
\text { - Mokykliniai renginiai, viktorinos, popietės, kurių metu sužinoma apie sveiką mitybą, } \\
\text { modernias ir tradicines maisto technologijas, tradicijas ir papročius, maisto etnografiją } \\
\text { - Kritinio požiūrio ị greitmaisčio kultūrą ugdymas } \\
\text { - Tėvų įtraukimas į mokyklos sveikos gyvensenos programas } \\
\text { - Ekskursijos, išvykos }\end{array}$ \\
\hline \multirow[b]{2}{*}{$\begin{array}{l}\text { MIKRO } \\
\text { LYGMUO }\end{array}$} & Šeimos funkcijos \\
\hline & $\begin{array}{l}\text { - Tinkamas vyresnių šeimos narių asmeninès elgsenos pavyzdys } \\
\text { - Kritinio požiūrio ị greitmaisčio kultūrą ugdymas } \\
\text { - Sveikos mitybos ir sveikos gyvensenos bibliotekèlè, informavimas internetu, nuo- } \\
\text { latinis mokymasis, šeimos narių buvimas patirtinio mokymosi tinkluose ir pan. } \\
\text { - Sveiko maisto pirkimo (igijimo) namų ūkyje patirtis } \\
\text { - Ekologinès žemdirbystès elementai namų ūkyje (mini daržas balkone, daržas so- } \\
\text { dyboje), vaikų ịtraukimas ị atitinkamas veiklas } \\
\text { - Sveiko maisto ruošimo ir saugojimo namų ūkyje technologijų ịsisavinimas } \\
\text { - Maitinimosi etnokultūros dalykai } \\
\text { - Maitinimosi integravimas ị šeimos šventes, tradicijas ir ritualus } \\
\text { - Apsinuodijimų ir susirgimų prevencija, maisto higienos ịpročių ugdymas } \\
\text { - Mitybos perversijų (radikalios dietos, papildai, dopingas, badavimas, anoreksija } \\
\text { ir kt.) prevencija }\end{array}$ \\
\hline
\end{tabular}


knyga „Sveikos mitybos ir fizinio aktyvumo skatinimas: antsvorio, nutukimo ir lètinių ligų prevencija Europos Sąjungoje"15; Lietuvos Respublikos visuomenès sveikatos priežiūros įstatymas ${ }^{16}$. Lietuvos mokyklose, remiantis ŽŪM ir ES teisès aktais ${ }^{17}$, vykdomos programos ${ }^{18}$ „Pienas vaikams“ ir „Vaisių vartojimo skatinimo“, siekiant pagerinti vaikų mitybos įpročius bei skatinti sveiką gyvenseną.

Šeimos, mokyklos ir valstybès bendradarbiavimo funkcinis modelis: vaikų sveikos mitybos aspektas. Vaikystès amžiaus tarpsnis yra labai svarbus formuojantis individo įpročiams. Šios trivialios, tačiau fundamentalios tiesos supratimas taikliai užfiksuotas ir mūsų tautosakoje: „lenk medị, kol jaunas“, ,pripratimas - blogiau prigimimo" ir pan. Būtent vaikysteje formuojasi daugelis pamatinių elgesio ịpročių, pvz., higieniniai, maitinimosi ịpročiai, kurie išlieka visą gyvenimą. Vaikystejje, jaunystejje natūraliai priprantama ir prie tam tikro valgiaraščio, susiformuoja sąlyginai pastovios konkrečių maisto produktų preferencijos. Tarkime, jeigu vaikas iš mažens priprato gerti arbatą be cukraus, mažai tikètina, kad sulaukęs 30 ar juolab 50 metų, jis pradès dèti sau ị puodelị po 3-4 šaukštelius cukraus... Būtent vaikystėje, paauglystėje turi susiformuoti ir žmogaus gebejjimas reflektuoti, kontroliuoti, stebėti, kas valgoma ir kaip valgoma $[2,16,20,21,22,28,33]$. Šis gebejjimas sveikos mitybos požiūriu yra labai svarbus, nekalbant jau apie tai, kad jis yra gana patikima apsinuodijimų maistu, taip pat pavojingų ligų, kuriomis užsikrečiama per maistą, prevencijos priemonė.

Šiuolaikinis mokinys turètų gauti žinių ir apie maisto rengimo ir saugojimo technologijas buityje, tureti supratimą apie maisto produktų vartojimo instrukcijas bei jo saugo-

${ }^{15}$ Žalioji knyga „Sveikos mitybos ir fizinio aktyvumo skatinimas: antsvorio, nutukimo ir chroniškų ligų prevencija Europos Sajungoje“. [žiūrèta 2016 m. kovo 28 d.]. Prieiga per internetą: http://eur-lex.europa.eu/legalcontent/LT/TXT/PDF/?uri=CELEX:52005DC0637\&from=LT

${ }^{16}$ Lietuvos Respublikos visuomenès sveikatos priežiūros įstatymas (Žin., 2002, Nr. IX-886). [žiūrèta 2016m. kovo 28d.]. Prieiga per internetą: https:// www.e-tar.lt/portal/lt/legalAct/TAR.DD80CF948782

${ }^{17}$ LR ŽŪM ịsakymas „Dèl vaisių vartojimo skatinimo vaikų ugdymo ìstaigose programos 2014-2017 mokslo metų strategijos patvirtinimo“ $2014 \mathrm{~m}$. balandžio $30 \mathrm{~d}$. Nr. 3D-250. Vilnius. [žiūrèta 2016m. kovo 10d.]. Prieiga per internetą: http://www3.lrs.lt/pls/inter3/dokpaieska.showdoc_1?p_ $\mathrm{id}=470272 \& p \_$tr2 $=2$; LR ŽŪM įsakymas „Dèl žemès ūkio ministro 2008 m. rugpjūčio 27 d. ịsakymo nr. 3d-478 „Dèl paramos už pieną vaikams administravimo taisyklių patvirtinimo" pakeitimo" $2014 \mathrm{~m}$. lapkričio $6 \mathrm{~d}$. Nr. 3D-832, Vilnius. [žiūrèta 2016m. kovo 15d.]. Prieiga per internetą: http:// www.litfood.lt/naujienos/pienas-vaikams-patvirtintas-lesu-limitas-vienamvaikui-per-menesi-ateinantiems-2014-2015-mokslo-metams/

${ }^{18}$ Vaisių vartojimo skatinimo mokyklose programa. [žiūrèta $2016 \mathrm{~m}$. kovo 10d.]. Prieiga per internetą: http://ec.europa.eu/health/highlights/2012/15/short_content_lt.htm; Pieno produktų vartojimo vaikų ir švietimo ịstaigose paramos programa „Pienas vaikams“. [žiūrèta $2016 \mathrm{~m}$. kovo 10d.]. Prieiga per internetą: http://www.litfood.lt/naujienos/pienasvaikams-patvirtintas-lesu-limitas-vienam-vaikui-per-menesi-ateinantiems2014-2015-mokslo-metams/ jimą, maisto energetinę vertę, kalorijų poreikį, priklausomai nuo gyvenimo būdo ir fizinio aktyvumo. Vaikui turètų būti suformuota fundamentali vertybinè motyvacinè sveikos gyvensenos ir mitybos nuostata. Žinoma, lengva pasakyti, tačiau sunku padaryti.

1 lenteleje pateikiamas holistinis vaikų sveikos mitybos ipročių ugdymo darbinis-hipotetinis modelis. Jame parodyta, kokias funkcijas, ugdant vaikų sveikos mitybos įpročius, galètų ir turètų atlikti valstybè, mokykla ir šeima.

Šiandien bet kuris išsilavinęs žmogus, galima daryti prielaidą, iš esmès neabejoja sveikos gyvensenos ir sveikos mitybos nauda. Deja, egzistuoja milijonai žmonių, kurių teorinès žinios ir pažiūros apie sveiką gyvenseną yra teisingos, tačiau teorines žinias nuo faktinès elgsenos skiria didžiulè praraja. Teisingos teorinès žinios nevirsta tinkama faktine elgsena. Didžiulè masė žmonių dèl valios stokos, dèl susiformavusių ir užsifiksavusių ydingų ịpročių elgiasi inertiškai, gyvena ir maitinasi labai nesveikai. Galima daryti prielaidą, kad dalis žmonių, kurių teisingos, pažangios teorinès pažiūros ir faktiné sveiko maitinimosi elgsena harmoningai sutampa, sudaro sąlyginę mažumą. Kaip kitaip galima būtų paaiškinti masinio nutukimo epidemiją moderniose Vakarų visuomenèse?

\section{Išvados}

1. Nepaisant medicinos mokslo ir klinikinès praktikos pažangos, vaikų sveikatos rodikliai negerejja. Viena iš vaikų sveikatos rodiklių prastėjimo priežasčių yra gyvenimo būdo mulemtos ligos, kylančios del perdetai kaloringo maisto ir hipodinamijos. Sveikos mitybos samprata ir objektyvi raiška neatsiejama nuo asmens (vaiko) fizinio aktyvumo. Modernybė greta pažangos ir didelių galimybių vis dèlto sukuria didelius iššūkius žmogaus ir vaiko sveikatai. Tai - maisto chemizacija, maisto rengimo ir saugojimo technologijų, sociokultūrinių maitinimosi ritualų kaita.

2. Išsakyti samprotavimai rodo, kad sveika gyvensena ir sveika mityba yra, viena vertus, didelè visuomeninè vertybè ir didžiulis viešasis gèris. Kita vertus, tai labai svarbus šiuolaikinio žmogaus (ir vaiko) ugdymo turinio komponentas bei išskirtinès svarbos ugdymo tikslas. Turint galvoje didžiuli, kartais beviltišką atotrūkị tarp teisingo teorinio žinojimo ir ydingos faktinès individų elgsenos, akivaizdu, jog sveikos mitybos ịpročių išugdymas yra labai sudètingas ir giliai kompleksinis ugdymo tikslas. Šis tikslas apima asmenybès kognityvinę, vertybinę, emocinę (afekto) sferas bei faktinès individo elgsenos struktūras. Akivaizdu, jog šiandien vis dar stinga mokslo žinių ir praktinių edukacinių technologijų, kurios padètų patikimai ir stabiliai ịveikti minètą atotrūkị tarp teisingo mūsų teorinio žinojimo ir ydingos faktinès daugybès individų elgsenos. 
3. Siekiant išugdyti vaikų ir paauglių sveikos mitybos ịpročius, turi būti konsoliduojama visų socializacijos instancijų veikla, palanki ugdymo(si) aplinka kuriama visais imanomais lygiais - makro, mezo ir mikro lygmenimis. 1 lenteleje pateikiamas holistinis vaikų sveikos mitybos ịpročiu ugdymo darbinis-hipotetinis modelis. Modelyje apibendrintai parodyta, kokias funkcijas galètų ir turètų, ugdant vaikų sveikos mitybos ịpročius, atlikti valstybè, mokykla ir šeima.

\section{Literatūra}

$1.2014 \mathrm{~m}$. Lietuvos gyventojų sveikatos statistinio tyrimo rezultatai. Vilnius: Lietuvos statistikos departamentas, 2015.

http://www.ntakd.lt/index.php/statistika/tyrimai-ir-apklausos

2. Bocca G, Kuitert MWB, Sauer PJJ, Stolk RP, Flapper BC, Corpeleijn E. A multidisciplinary intervention programme has positive effects on quality of life in overweight and obese preschool children. Acta Pædiatrica 2014;103:962-967.

https://doi.org/10.1111/apa.12701

3. Common plastics chemical linked to heart problems. Romanian Journal of Medical Practice 2008;3(3):121-121.

4. Dabriegaitè V, Dudonienè V, Imbrasienè D, Kesminas R. Mitybos ir fizinio aktyvumo poveikis moksleiviu elgesiui ir akademiniams pasiekimams. Reabilitacijos mokslai: slauga, kineziterapija, ergoterapija, 2013;1(8):4-8.

5. Danielsen YS, Júlíusson PB, Nordhus IH, Kleiven M, Meltzer HM, Olsson SJG, Pallesen S.The relationship between life-style and cardio-metabolic risk indicators in children: The importance of screen time. Acta Paediatrica 2011;100(2):253-259. https://doi.org/10.1111/j.1651-2227.2010.02098.x

6. De Henauw S, Verbestel V, Mårild S, et.al. The IDEFICS community-oriented intervention programme: a new model for childhood obesity prevention in Europe? International Journal of Obesity 2011; 35, S16-S23. http://www.ncbi.nlm.nih.gov/ pubmed/21483418

https://doi.org/10.1038/ijo.2011.31

7. Dhalwani NN, O'Donovan G, Zaccardi F, Hamer M, Yates T, Davies M, Khunti K. Long terms trends of multimorbidity and association with physical activity in older english population. International Journal of Behavioral Nutrition \& Physical Activity 2016;13:1-9.

https://doi.org/10.1186/s12966-016-0330-9

8. Dundulienė P. Duona lietuvių buityje ir papročiuose. Vilnius: Mokslo ir enciklopedijų leidybos centras 2007:123.

9. Fasano E, Esposito F, Scognamiglio G, Di Francesco F, Montuori P, Cocchieri AR, Cirillo T. Bisphenol A contamination in soft drinks as a risk for children's health in italy. Food Additives \& Contaminants. Part A: Chemistry, Analysis, Control, Exposure \& Risk Assessment 2015;32(7):1207-1214.

https://doi.org/10.1080/19440049.2015.1031713

10. Figueras J, McKee M. Health system, health, wealth and societal well-being. Assessing the case for investing in health system. Maidenhead, Berkshire: McGraw-Hill Education 2012:330.

11. Georgescu B, Georgescu CE. Bisphenol a levels in commercial milk, infant formula and dairy products. Animal Biology \& Animal Husbandry 2013;5(2):171-174.

12. Grabauskas V, Klumbienė J, Petkevičienè J, Šakytė E, Kriaučionienè V, Veryga A. Suaugusių Lietuvos žmonių gyvensenos tyrimas. Kaunas: Lietuvos sveikatos mokslų universitetas, 2015. http://www.ntakd.lt/index.php/statistika/tyrimai-ir-apklausos.

13. Gracia-Marko L, Vicente-Rodriquez G, Casajus JA, Molnar D, Castilo MJ. Effect of fitness and physical activity on bone mass in adolescents: the HELENA study. European Journal Applied Physiology 2011; 111: 2671-2680. http://www.helenastudy. com/scientific.php https://doi.org/10.1007/s00421-011-1897-0

14. Griškonis S, Strukčinskienẻ B, Strazdienè N. Vakarų Lietuvos ikimokyklinio amžiaus vaikų mitybos ypatumai: Šilutes rajono atvejis. Sveikatos mokslai, 2011;4(21):42-47.

15. Gudžinskienè V, Česnavičienė J. Mokytojų žinios apie sveikatą ir sveiką gyvenseną kaip mokinių sveikos gyvensenos ugdymo prielaida. Socialinis darbas, 2013;12(1):121-136.

https://doi.org/10.13165/SD-13-12-2-10

16. Hamilton K, Thomson CE, White KM. Promoting active lifestyles in young children: investigating mothers' decisions about their child's physical activity and screen time behaviours. Maternal and Child Health Journal 2013;17:968-976. https://doi.org/10.1007/s10995-012-1081-0

17. Institute of Medicine (U.S.) Nutrition standards for foods in schools: leading the way toward healthier youth. Washington DC.: National Academies Press 2007:296.

18. Institute of Medicine. Early childhood obesity prevention policies. Washington DC: National Academies Press 2011:202.

19. Lagūnaite $\mathrm{R}$, Zaborskis A. Ar vaikų mitybos gerinimo programos yra veiksmingos: sisteminé straipsnių apžvalga. Visuomenès sveikata, 2011;4(55):18-29.

20. Mareno N. Parental perception of child weight: a concept analysis. Journal of Advanced Nursing 2014;70(1):34-45.

https://doi.org/10.1111/jan.12143

21. Mirza NV, GaakAY. Modern aspects of healthy lifestyle formation in preschool children. European Researcher 2013;57:8-2.

22. Moraeus L, Lissner L, Yngve A, Poortvliet E, Al-Ansari U, Sjöberg A. Multi-level influences on childhood obesity in Sweden: societal factors, parental determinants and child's lifestyle. International Journal of Obesity 2012;36:969-976. https://doi.org/10.1038/ijo.2012.79

23. Petrauskienẻ A, Albavičiūte E, Žaltauskẻ V, Navardauskaitė T. Penkių didžiưjų Lietuvos miestų pirmokų mitybos ịpročiai. Visuomenès sveikata, 2012;4(59):103-109.

24. Petrauskienė A, Albavičiūtė E, Žaltauskè V. Lietuvos vaiku augimo stebėsena: rezultatai ir pokyčiai (2008-2013 m). Vi- 
suomenès sveikata, 2014; 3(66):31-39.

25. Ruiz RJ, Ortega FB, Martinez-Gomez D, Labayen I, et.al. Objectively measured physical activity and sedentary time in European adolescents. The HELENA study. American Journal of Epidemiology 2011. http:/www.helenastudy.com/ scientific.php

https://doi.org/10.1093/aje/kwr068

26. Schoeppe S, Trost SG. Maternal and paternal support for physical activity and healthy eating in preschool children: a cross-sectional study. BMC Public Health 2015;15(1):1-7.

https://doi.org/10.1186/s12889-015-2318-9

27. Sichert-Hellert W, Beghin L, De Henauw S, Grammatikaki E, Hallström L, Manios Y. Nutritional knowledge in European adolescents: results from the HELENA (Healthy Lifestyle in Europe by Nutrition in Adolescence) study. Public Health Nutrition 2011;14(12):2083-2091. https://doi.org/10.1017/S1368980011001352

28. Sylvetsky-Meni AC, Gillepsie SE, Hardy T, Welsh JA. The impact of parents' categorization of their own weight and their child's weight on healthy lifestyle promoting beliefs and practices. Journal of Obesity 2015. Article ID 307381:7. https://doi.org/10.1155/2015/307381

29. Simkiss D. Children and society policy review: health policy affecting children and young people. Children \& Society 2013; 27(3), 233-239.

https://doi.org/10.1111/chso.12021

30. Stukas R, Savickaja K, Bartusevičiūtė R, Dobrovolskij V. Vilniaus pradinių mokyklų mokinių mitybos ypatumai. Sveikatos mokslai, 2011; 21(7):85-90.

31. Wethington H, Pan L, Sherry B. The association of screen time, television in the bedroom, and obesity among school-aged youth: 2007 National Survey of Children's Health. Journal of School Health 2013;83:573-581. https://doi.org/10.1111/josh.12067

32. Whiting L, Kendall S, Wills W. The importance of research and participation in formulating child health policy. Nursing Children \& Young People 2012;24(10):18-20. https://doi.org/10.7748/ncyp2012.12.24.10.18.c9462

33. Willis TA, George J, Hunt C, Roberts KPJ, Evans CEL, Brown RE, Rudolf MCJ. Combating child obesity: impact of HENRY on parenting and family lifestyle. International Association for the Study of Obesity. Pediatric Obesity 2013;9:339-350. https://doi.org/10.1111/j.2047-6310.2013.00183.x
34. Zaborskis A, Lagūnaitė R. Vaisiai ir daržovès mokinio valgiaraštyje: mityba ir socialiniai netolygumai 2002-2010 metais. Visuomenès sveikata, 2011;1/2(53):65-75.

35. Довидайтис Ю. Здоровое питание детей и обучающейся молодежи как объект координирования секторных политик государства//Высшая школа: опыт, проблемы, перспективы: материалы XIII международной научнопрактической конференции. Москва, РУДН, 2-3 апреля 2020 г. / Науч.ред. В.И. Казаренков. Москва: РУДН (in press).

\section{EDUCATION OF CHILDREN HEALTHY NUTRITION: COLLABORATION OF THE STATE, SCHOOL AND FAMILY \\ J. Dovydaitis}

Keywords: healthy lifestyle and nutrition, family, school, State. Summary

The article shows that children's healthy eating problem in post-modern society becomes a real and very threatening challenge. A paradox appears: medicine and child rights standards are constantly rising, but the children are eating poorer food, and they $\mathrm{n}$ face an increasing amount of diseases that are primarily caused by poor nutrition and a sedentary lifestyle. From the point of view of children's health, criticism is given to increased use of chemicals on food, which is caused by environmental pollution, as well as the egoistic interests of producers and traders. Fast-food culture, which is increasingly overwhelming families and schools, is also criticized. Family is revealed to have a role as a socializing institution in shaping children's healthy eating habits and knowledge for life. There is an overview of Lithuanian and worldwide healthy diet and lifestyle monitoring system for children, as well as healthy children's nutrition policy, appropriate health promotion programs and measures. The article raises the hypothesis that a positive breakthrough in the implementation of children's healthy diet is likely to occur when everything is coordinated, more or less, on all of these possible levels: 1) the macro level (government policies, laws, programs, social advertising, etc.); 2) meso level (school); 3) a micro level (family, individual and microenvironment). This article attempts to purify all these levels and social institution functions that form children's stable and healthy eating habits.

Correspondence to: julius.dovydaitis@go.kauko.lt

Gauta 2020-10-29 